\title{
Prognostic significance of reactive pulmonary hypertension in patients with chronic heart failure listed for elective heart transplantation
}

\author{
Małgorzata Sobieszczańska-Małek ${ }^{1}$, Tomasz Zieliński ${ }^{1}$, Walerian Piotrowski ${ }^{2}$, Jerzy Korewicki ${ }^{1}$ \\ ${ }^{1}$ Heart Failure and Transplantology Department, Institute of Cardiology, Warsaw, Poland \\ ${ }^{2}$ Department of Epidemiology, Cardiovascular Diseases Prevention, and Promotion of Health, Institute of Cardiology, Warsaw, Poland
}

\begin{abstract}
Background: Pulmonary hypertension $(\mathrm{PH})$ is recognised in about $60 \%$ of patients referred for heart transplantation (HTx), and it influences the patient's prognosis.

Aim: To assess the prognostic value of reactive $\mathrm{PH}$ in patients listed for elective HTx.

Methods: A total of 522 patients were enlisted from the Polish National Registry (POLKARD), listed for HTx, in whom complete haemodynamic data were reported. The endpoint was all-cause death before HTx. Heart transplantation, elective or urgent, was considered as an end of the follow-up (mean follow-up $1.47 \pm 1.26$ years). Patients were divided into three subgroups: no $\mathrm{PH}$, passive $\mathrm{PH}$, reactive $\mathrm{PH}$ taking into account mean pulmonary artery pressure (PAP) of $25 \mathrm{~mm} \mathrm{Hg}$, pulmonary capillary wedge pressure (PCWP) $15 \mathrm{~mm} \mathrm{Hg}$, and pulmonary vascular resistance (PVR) 3.0 Wood units. Haemodynamic, clinical, echocardiographic, and biochemical assessments (including NT-proBNP, hs-CRP) were performed. The Heart Failure Survival Score (HFSS) was calculated.

Results: Estimated death rate was comparable between patients with no $\mathrm{PH}$, passive $\mathrm{PH}$, and reactive $\mathrm{PH}$, despite the fact that the patients with reactive PH had the worst pulmonary haemodynamic scores (mean PAP 38.4 $\pm 7.8, \mathrm{PCWP} 27 \pm 7.4 \mathrm{~mm} \mathrm{Hg}$ and PVR 4.8 \pm 1.7 Wood units). In patients with reactive PH, in multifactor Cox analysis only the serum Na level influenced survival. According to the Kaplan-Meier method, patients with reactive $\mathrm{PH}$, with mean PAP $\geq 41.4 \mathrm{~mm} \mathrm{Hg}$ had the worst prognosis, estimated survival was: one year $-83 \%$, two years $-65 \%$.

Conclusions: Reactive PH is common among patients with chronic HF listed to HTx (28\%). It has no further influence on short-term prognosis as compared with patients with no $\mathrm{PH}$ and passive $\mathrm{PH}$. Serum $\mathrm{Na}$ concentration and mean $\mathrm{PAP} \geq 41.4 \mathrm{~mm} \mathrm{Hg}$ influence the prognosis of patients with reactive $\mathrm{PH}$.
\end{abstract}

Key words: heart transplantation, pulmonary hypertension

Kardiol Pol 2016; 74, 8: 733-740

\section{INTRODUCTION}

Left ventricular (LV) dysfunction and failure causes an increase in LV filling pressure and is responsible for the rise in left atrial pressure and in pulmonary venous and arterial bed. The mean pulmonary artery pressure (mPAP) is closely related to pulmonary capillary wedge pressure (PCWP), left atrial pressure, and with LV filling pressure in patients with LV heart failure (HF). Elevated PCWP can cause remodelling of the pulmonary vascular bed. Arterialisation of pulmonary veins is the first step to reactive pulmonary hypertension (reactive $\mathrm{PH}$ ) with further structural changes of pulmonary arteries [1-4].

Increased pulmonary vascular resistance (PVR) and increased transpulmonary gradient (TPG) are the result of reactive $\mathrm{PH}$ and have an influence on the morbidity and mortality of patients with HF [3-9]. Pulmonary hypertension $(\mathrm{PH})$ is recognised in 50-60\% of patients referred for heart transplantation (HTx) and has, according to some authors, a significant influence on patient's prognosis. Contrary to 
that, some authors have reported that patients with chronic $\mathrm{HF}$ have poor prognosis and that $\mathrm{PH}$ has no further influence on prognosis at this stage of disease $[9,10]$.

Patients with chronic HF listed for HTx are a highly selected population because of the strict qualification/disqualification criteria. $\mathrm{PH}$ and elevated PVR are considered as a relative contraindication when there is no response to "vasodilator challenge". Nevertheless, numerous studies have shown that this model of $\mathrm{PH}$ (reversible) is associated with worse prognosis [10].

The main aim of the study was to assess the prognostic value of reactive $\mathrm{PH}$ (reversible) in patients with chronic HF waiting for HTx in comparison with the rest of the qualified patients (with no $\mathrm{PH}$ and with passive $\mathrm{PH}$ ).

The results could improve allocation criteria to HTx among patients listed for elective transplantation.

\section{METHODS}

Within five years (2003-2007) 658 patients with chronic HF according to the United Network for Organ Sharing (UNOS-2) were listed for HTx in Poland and were included into the registry. The average period of observation was 601 days (1-1462 days). All patients underwent standard evaluation including right heart catheterisation [11]. Further analysis concerned only those in whom the complete right heart haemodynamic protocol was reported (522 patients; 79.3\%). Apart form the haemodynamic measurements (mPAP, PCWP, TPG, PVR), precise clinical, echocardiographic, electrocardiographic and biochemical assessments (including $\mathrm{N}$-terminal pro B-type natriuretic peptide [NT-proBNP], and high-sensitivity $\mathrm{C}$-reactive protein [hs-CRP]) were performed.

Heart Failure Survival Score (HFSS) according to Aaronson was calculated. The HFSS was derived in each patient from the seven clinical parameters: heart rate $(\mathrm{HR})$, LV ejection fraction (LVEF), serum sodium ( $\mathrm{Na}$ ), peakVO $\mathrm{O}_{2}$ max, intraventricular conduction delay (IVCD), and ischaemic heart disease $($ IHD; yes $=1$, no $=0)$. The seven products were summed and the absolute value determined according to the following equation: HFSS $=[(0.0216 \times$ resting $\mathrm{HR}(0.025 \times$ mean blood pressure $)+(0.0464 \times$ LVEF $)+(0.047 \times$ serum $\mathrm{Na})+\left(0.0546 \times\right.$ peakVO$\left._{2}\right)+(0.608 \times$ presence or absence of IVCD $)+(0.6931 \times$ presence or absence of IHD)]. For the HFSS, risk strata were defined as low risk $(\geq 8.10)$, medium risk (7.20-8.09), or high risk $(\leq 7.19)$, using previously described cut-offs [4].

The whole group (522 patients) was divided into three subgroups: no $\mathrm{PH}$, passive $\mathrm{PH}$, reactive $\mathrm{PH}$ according to the Aronson definitions: no $\mathrm{PH}$ subgroup $-\mathrm{mPAP}<25 \mathrm{~mm} \mathrm{Hg}$; passive $\mathrm{PH}$ subgroup - $\mathrm{mPAP} \geq 25 \mathrm{~mm} \mathrm{Hg}, \mathrm{PCWP} \geq 15 \mathrm{~mm} \mathrm{Hg}$, and $P V R<3.0$ Wood Units (WU), reactive $\mathrm{PH}$ subgroup $\mathrm{mPAP} \geq 25 \mathrm{~mm} \mathrm{Hg}, \mathrm{PCWP} \geq 15 \mathrm{~mm} \mathrm{Hg}$, and $\mathrm{PVR} \geq 3.0 \mathrm{WU}$ [5].

The endpoint of the study was all-cause death. Heart transplantation, elective or urgent, was considered as an end of the follow-up. All patients were followed up and treated with optimal doses of angiotensin converting enzyme inhibitors, beta-blockers, and diuretics by cardiologists in the Heart Failure and Transplantology Departments in four participating transplantology centres in Poland and appropriate outpatient's clinics.

Informed consent was obtained from each patient participating in the study, according to the protocol approved by the Local Ethics Committee. The investigation conformed to the principles outlined in the Declaration of Helsinki.

The results presented are part of the national POLKARD-HF programme (gov.no.NCT 00690157).

\section{Statistical analysis}

All calculations were performed with SAS version 9.2 software. Continuous data are reported as mean \pm standard deviation. In the case of a skewed distribution the median with the range is presented. Differences between groups for continuous data were tested with nonparametric analysis of variance by the Kruskal-Wallis test. Differences between groups for proportions were tested with the $\chi^{2}$ test. Since both cardiac variables (hs-CRP and NT-proBNP) are not normally distributed, these variables were transformed logarithmically to meet the assumptions for linear regression analysis. Cardiac survival was estimated with the Kaplan-Meier method; differences were tested with log rank test - the endpoint of the study was all-cause death, the end of observation (censored) - HTx urgent or elective. Univariable and multivariable Cox-regression analyses were performed to investigate the association of pre-measurements with incidents of death. Independent variables in multivariable analysis were selected by stepwise option.

For all analyses, a two-sided p-value $<0.05$ was considered to indicate statistical significance.

\section{RESULTS \\ Patient's characteristics}

A total of 658 patients with stable chronic HF were listed for elective (UNOS 2) HTx and registered in a national registry. In 522 (79.3\%), complete haemodynamic data concerning pulmonary circulation were obtained. The main causes of HF were ischaemic cardiomyopathy (46.4\%) and dilated cardiomyopathy $(47.7 \%)$. The average age of patients was 50 years; most of them were male (87.8\%). There were patients with chronic HF - $84 \%$ of them were in New York Heart Association (NYHA) functional classes III and IV. The mean value of LVEF was $20.7 \pm 7.7 \%$. The end-diastolic diameter of LV (LVEDD) was $72.2 \pm 10.3 \mathrm{~mm}$. More than $60 \%$ of patients had $\mathrm{PH}-\mathrm{mPAP}$ was $28.5 \pm 11.2 \mathrm{~mm} \mathrm{Hg}$; PCWP exceeded $20 \mathrm{~mm} \mathrm{Hg}$ $(21.0 \pm 9.5)$, TPG was $10.1 \pm 5.6 \mathrm{~mm} \mathrm{Hg}$. The mean value of cardiac index $(\mathrm{Cl})$ was less than 2.0 liters $\left(1.9 \pm 0.9 \mathrm{~L} / \mathrm{min} / \mathrm{m}^{2}\right)$. NT-proBNP median value was $2703 \mathrm{pg} / \mathrm{mL}$. The Aaronson score (HFSS) indicating medium risk $7.7 \pm 0.9$ (Table 1). All 
Table 1. Characteristics of all the patients

\begin{tabular}{|lc|}
\hline Age [years] & $50.0 \pm 10.3$ \\
LVEF [\%] & $20.7 \pm 7.7$ \\
LVEDD [mm] & $72.2 \pm 10.3$ \\
LVESD [mm] & $60.9 \pm 12.4$ \\
HR $/ / \mathrm{min}]$ & $78.4 \pm 15.3$ \\
SBP [mm Hg] & $100.9 \pm 14.1$ \\
DBP [mm Hg] & $66.1 \pm 10.4$ \\
Na [mEq/L] & $136.2 \pm 4.4$ \\
VO ${ }_{2} \mathrm{max}[\mathrm{mL} / \mathrm{min} / \mathrm{kg}]$ & $12.2 \pm 3.6$ \\
HFSS & $7.7 \pm 0.9$ \\
mPAP [mm Hg] & $28.5 \pm 11.2$ \\
PCWP [mm Hg] & $21.0 \pm 9.5$ \\
TPG [mm Hg] & $10.1 \pm 5.6$ \\
Cardiac index [L/min/m²] & $1.9 \pm 0.9$ \\
PVR [WU] & $3.2 \pm 2.4$ \\
hs-CRP [mg/L] & $3.3(0.03-347.0)$ \\
NT-proBNP [pg/mL] & $2703(77-45515)$ \\
\hline
\end{tabular}

Data are presented as mean \pm standard deviation or median and range (min-max); LVEF — left ventricular ejection fraction; LVEDD — left ventricular end-diastolic diameter; LVESD - left ventricular end-systolic diameter; HR — heart rate; SBP — systolic blood pressure; DBP — diastolic blood pressure; HFSS - Heart Failure Survival Score; mPAP mean pulmonary artery pressure; PCWP — pulmonary capillary wedge pressure; TPG — transpulmonary gradient; PVR - pulmonary vascular resistance; WU - Wood Unit; hs-CRP — high-sensitivity C-reactive protein; NT-proBNP — N-terminal pro B-type natriuretic peptide

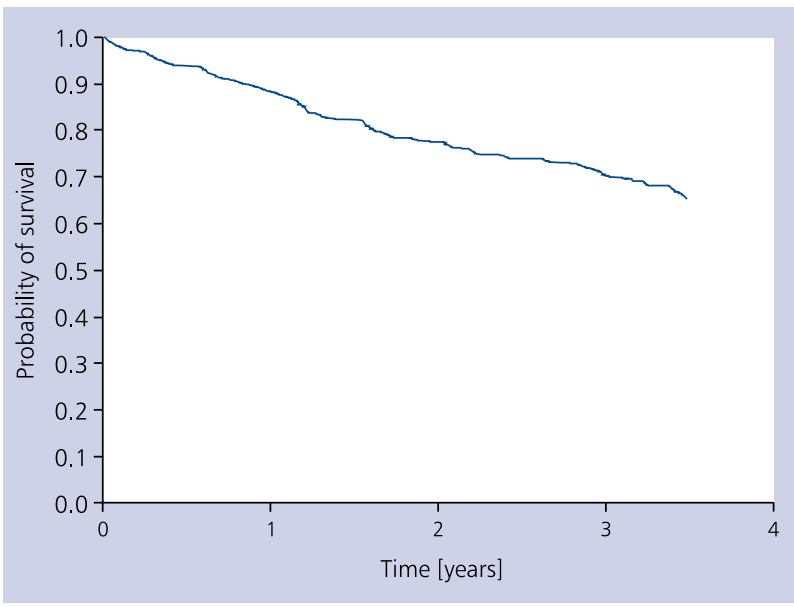

Figure 1. Probability of survival in patients with chronic heart failure - all group

group one-year survival (Kaplan-Meier method) was about $88 \%$, two years - about $77 \%$ (Fig. 1 ).

In total 325 (49.39\%) patients were transplanted. Ninety (27.7\%) died after HTx. The univariate Cox regression model revealed: end-systolic diameter of LV (LVESD), LVEDD, LVEF, mean PCWP, NT-proBNP, VO max, HFSS, and serum Na levels influenced the patient's prognosis (Table 2). The multifactor Cox regression model indicated that only LVEDD (HR 1.04; CI 1.010-1.070), $\mathrm{VO}_{2} \max (\mathrm{HR} 0.899, \mathrm{Cl} 0.827-0.978$ ) level, and serum $\mathrm{Na}(\mathrm{HR} 0.937, \mathrm{Cl}$ 0.889-0.988) level influenced survival.

\section{The characteristics and prognosis of patients with no PH listed for elective $H T_{x}$}

This was the oldest group as compared with the others either passive or reactive $\mathrm{PH}$.

The mean value of LVEF ( $22 \pm 8.5 \%$ ) was higher than LVEF in patients with passive or reactive $\mathrm{PH}$. Systolic and diastolic diameters of LV assessed by echocardiography were comparable with those in the two other groups. The median level of NT-proBNP was the lowest in comparison with the other groups. HFSS was $7.8 \pm 0.9$. The mean value of: $\mathrm{mPAP}$ was $19.9 \pm 3.1 \mathrm{~mm} \mathrm{Hg}$, PCWP $14.1 \pm 3.0 \mathrm{~mm} \mathrm{Hg}$, TPG $7.7 \pm 3.9 \mathrm{~mm} \mathrm{Hg}$, PVR $2.2 \pm 1.3 \mathrm{WU}, \mathrm{Cl} 2.2 \pm 1.2 \mathrm{~L} / \mathrm{min}$ (Table 3).

The estimated death rate (Kaplan-Meier method) of patients with $\mathrm{HF}$ and no $\mathrm{PH}$ was comparable with the death rate of patients with passive or reactive $\mathrm{PH}$ (Fig. 2).

The univariate Cox regression model revealed that only NT-proBNP, HFSS, and serum Na levels influenced the patient's prognosis (Table 2). The multifactor Cox regression model indicated that LVEDD (HR 1.048, Cl 1.007-1.092), NT-proBNP (HR 1.002, Cl 1.001-1.003) level, and serum Na (HR 0.910, Cl 0.836-0.991) level influenced survival.

\section{Characteristics and prognosis of patients with passive $\mathrm{PH}$}

There were 163 (31\%) patients with LVEF: in $20.7 \pm 7.3 \%$ it was comparable with LVEF in patients with reactive $\mathrm{PH}$. Haemodynamic parameters were as follows: PCWP was $26.6 \pm 6.5 \mathrm{~mm} \mathrm{Hg}$, mPAP $34.0 \pm 6.6 \mathrm{~mm} \mathrm{Hg}$, TPG $8.1 \pm 3.5 \mathrm{~mm} \mathrm{Hg}, \mathrm{Cl} 1.9 \pm 0.5 \mathrm{~L} / \mathrm{min}, \mathrm{PVR} 2.2 \pm 0.7 \mathrm{WU}$ No differences between groups were recorded in terms of LVESD and LVEDD. There were also no differences in the levels of NT-proBNP, $\mathrm{VO}_{2}$ max, HFSS, and serum $\mathrm{Na}$ level between the groups of patients with passive or reactive $\mathrm{PH}$ (Table 3). No differences were found in estimated death rates between patients with no $\mathrm{PH}$ or reactive $\mathrm{PH}$ (Fig. 2).

Only NT-proBNP and $\mathrm{VO}_{2}$ max significantly influenced the patient's prognosis in the univariate Cox regression model (Table 2). Multifactor Cox regression analysis revealed that hs-CRP (HR 1.127, $\mathrm{Cl} 1.037-1.223$ ) and $\mathrm{VO}_{2} \max$ (HR 0.824, Cl 0.713-0.951) influenced the survival of patients with passive $\mathrm{PH}$.

\section{Characteristics and prognosis of patients with reactive $P H$}

This group consisted of 146 (28\%) patients. It was the youngest group as compared to others (49.8 \pm 10.4 years). Left ventricular dimensions assessed in echocardiography were comparable with respective echo measurements in patients 
Table 2. Univariate Cox regression analysis factors influencing survival

\begin{tabular}{|c|c|c|c|c|c|c|c|c|}
\hline & \multicolumn{2}{|c|}{ All group } & \multicolumn{2}{|c|}{$\begin{array}{c}\text { No PH } \\
\text { mPAP }<25 \mathrm{~mm} \mathrm{Hg}\end{array}$} & \multicolumn{2}{|c|}{$\begin{array}{c}\text { Passive PH } \\
\mathrm{mPAP} \geq 25 \mathrm{~mm} \mathrm{Hg} \\
\text { PCWP } \geq 15 \mathrm{~mm} \mathrm{Hg} \\
\text { PVR }<3.0 \mathrm{WU}\end{array}$} & \multicolumn{2}{|c|}{$\begin{array}{c}\text { Reactive PH } \\
\text { mPAP } \geq 25 \mathrm{~mm} \mathrm{Hg} \\
\text { PCWP } \geq 15 \mathrm{~mm} \mathrm{Hg} \\
\text { PVR } \geq 3.0 \mathrm{WU}\end{array}$} \\
\hline & HR & $95 \% \mathrm{Cl}$ & HR & $95 \% \mathrm{Cl}$ & HR & $95 \% \mathrm{Cl}$ & HR & $95 \% \mathrm{Cl}$ \\
\hline Age [years] & 0.998 & $0.997-1.019$ & 0.998 & $0.958-1.026$ & 1.003 & $0.970-1.037$ & 1.004 & $0.960-1.050$ \\
\hline LVEF [\%] & 0.958 & $0.927-0.990$ & 0.951 & $0.903-1.002$ & 0.979 & $0.929-1.030$ & 0.938 & $0.872-1.009$ \\
\hline LVEDD $[\mathrm{mm}]$ & 1.031 & $1.009-1.053$ & 1.026 & 0.994-1.059 & 1.009 & $0.970-1.051$ & 1.060 & $1.019-1.103$ \\
\hline LVESD $[\mathrm{mm}]$ & 1.025 & $1.007-1.044$ & 1.024 & $0.997-1.051$ & 1.006 & 0.973-1.039 & 1.050 & $1.013-1.088$ \\
\hline $\mathrm{HR}[/ \mathrm{min}]$ & 1.01 & $0.997-1.023$ & 1.009 & $0.990-1.028$ & 1.013 & $0.991-1.035$ & 1.010 & $0.981-1.039$ \\
\hline $\mathrm{SBP}[\mathrm{mm} \mathrm{Hg}]$ & 0.988 & $0.973-1.003$ & 0.996 & $0.975-1.017$ & 0.994 & $0.963-1.026$ & 0.965 & $0.932-0.999$ \\
\hline $\mathrm{DBP}[\mathrm{mm} \mathrm{Hg}]$ & 0.991 & $0.972-1.011$ & 1.012 & $0.985-1.040$ & 0.979 & $0.939-1.021$ & 0.965 & $0.926-1.005$ \\
\hline $\mathrm{Na}[\mathrm{mEq} / \mathrm{L}]$ & 0.922 & $0.884-0.962$ & 0.91 & $0.853-0.971$ & 0.927 & $0.850-1.010$ & 0.927 & $0.861-0.999$ \\
\hline $\mathrm{VO}_{2} \max [\mathrm{mL} / \mathrm{min} / \mathrm{kg}]$ & 0.916 & $0.861-0.974$ & 0.929 & $0.844-1.022$ & 0.878 & $0.777-0.993$ & 0.924 & $0.823-1.038$ \\
\hline HFSS & 0.648 & $0.518-0.811$ & 0.661 & $0.460-0.951$ & 0.680 & $0.451-1.024$ & 0.594 & $0.387-0.913$ \\
\hline $\mathrm{mPAP}[\mathrm{mm} \mathrm{Hg}]$ & 1.015 & $0.997-1.033$ & 0.989 & $0.924-1.059$ & 1.034 & $0.988-1.083$ & 1.051 & $1.008-1.097$ \\
\hline PCWP [mm Hg] & 1.023 & $1.002-1.044$ & 0.988 & $0.917-1.064$ & 1.039 & $0.992-1.088$ & 1.052 & $1.014-1.091$ \\
\hline TPG [mm Hg] & 1.000 & $0.914-1.095$ & 1.021 & $0.933-1.012$ & 0.981 & $0.917-1.048$ & 1.006 & $0.992-1.020$ \\
\hline Cardiac index $\left[\mathrm{L} / \mathrm{min} / \mathrm{m}^{2}\right]$ & 0.827 & $0.551-1.241$ & 1.111 & $0.764-1.616$ & 0.589 & $0.274-1.266$ & 0.260 & $0.078-0.862$ \\
\hline PVR [WU] & 1.003 & $0.932-1.079$ & 1.104 & $0.919-1.326$ & 1.598 & $0.916-2.786$ & 0.979 & $0.868-1.105$ \\
\hline hs-CRP [mg/L] & 1.006 & $0.989-1.026$ & 1.008 & $0.977-1.040$ & 1.007 & $0.973-1.043$ & 1.006 & $0.989-1.026$ \\
\hline NT-proBNP [pg/mL] & 1.002 & $1.001-1.003$ & 1.002 & $1.001-1.003$ & 1.002 & $1.001-1.003$ & 1.002 & $1.001-1.003$ \\
\hline
\end{tabular}

$\mathrm{Cl}$ - confidence interval; $\mathrm{HR}$ - hazard ratio; $\mathrm{PH}$ - pulmonary hypertension; other abbreviations as in Table 1

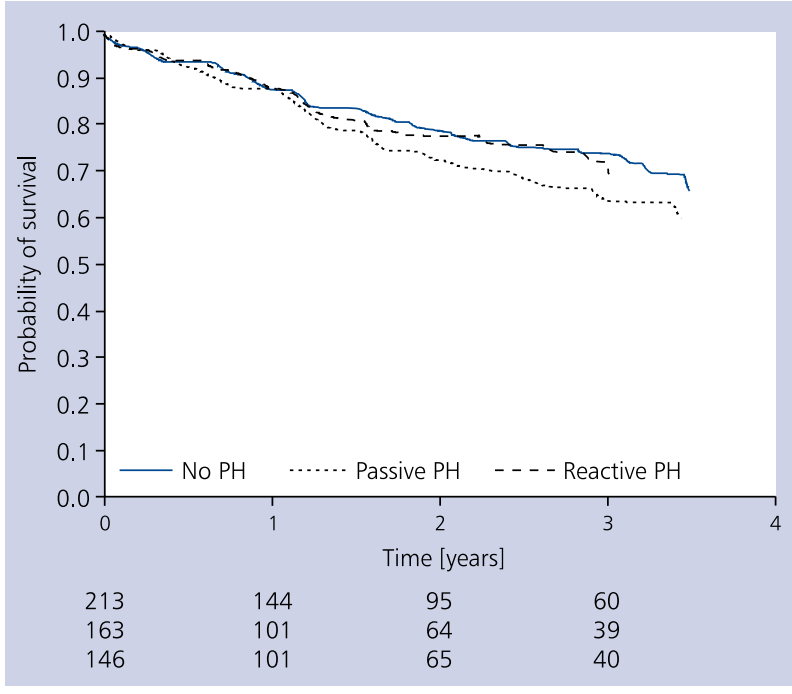

Figure 2. Probability of survival in patients with chronic heart failure and with no-pulmonary hypertension $(\mathrm{PH})$, passive $\mathrm{PH}$, and reactive $\mathrm{PH} ; \mathrm{p}=\mathrm{NS}$

with no $\mathrm{PH}$ or passive $\mathrm{PH}$. Mean PAP was $38.4 \pm 7.8 \mathrm{~mm} \mathrm{Hg}$, PCWP $27.0 \pm 7.4 \mathrm{~mm} \mathrm{Hg}$, TPG $15.6 \pm 5.8 \mathrm{~mm} \mathrm{Hg}, \mathrm{Cl}$
$1.6 \pm 0.5 \mathrm{~L} / \mathrm{min}, \mathrm{PVR} 4.8 \pm 1.7 \mathrm{WU}$. There were no differences in NT-proBNP, $\mathrm{VO}_{2}$ max, HFSS, and $\mathrm{Na}$ level between patients with passive or reactive $\mathrm{PH}$.

The prognosis of patients with reactive $\mathrm{PH}$ (Kaplan-Meier method) was comparable with patients with no or with passive $\mathrm{PH}$ (Fig. 2).

Among the parameters analysed, LVEDD, LVESD, systolic blood pressure, mPAP, PCWP, Cl, NT-proBNP, HFSS, and Na level significantly influenced patient survival in the univariate Cox regression model (Table 2). Multifactor regression analysis revealed that only serum $\mathrm{Na}$ level (HR 0.900, CI 0.823-0984) influenced the survival of patients with reactive $\mathrm{PH}$.

\section{DISCUSSION}

There are varied opinions concerning the influence of $\mathrm{PH}$ on the prognosis of patients who are candidates for HTx. Some authors have reported that patients with HF qualified for HTx have poor survival and that $\mathrm{PH}$ has no additive influence on their prognosis $[2,9,12,13]$.

The main aim of our study was to assess the prognostic value of reactive $\mathrm{PH}$ in ambulatory patients waiting for $\mathrm{HTx}$. That is a group of patients in whom functional as well as structural changes in pulmonary circulation can be suspected [5-9]. 
Table 3. Characteristics of patients according to pulmonary hypertension subgroups

\begin{tabular}{|c|c|c|c|c|c|c|}
\hline & $\begin{array}{c}\text { No PH } \\
\text { mPAP } \\
<25 \mathrm{~mm} \mathrm{Hg}\end{array}$ & $\begin{array}{c}\text { Passive PH } \\
\mathrm{mPAP} \geq 25 \mathrm{~mm} \mathrm{Hg} \\
\mathrm{PCWP} \geq 15 \mathrm{~mm} \mathrm{Hg} \\
\text { PVR }<3.0 \mathrm{WU}\end{array}$ & $\begin{array}{c}\text { Reactive PAH } \\
\mathrm{mPAP} \geq 25 \mathrm{~mm} \mathrm{Hg} \\
\mathrm{PCWP} \geq 15 \mathrm{~mm} \mathrm{Hg} \\
\mathrm{PVR} \geq 3.0 \mathrm{WU}\end{array}$ & $\begin{array}{c}\text { Group I } \\
\text { vs. } \\
\text { group II }\end{array}$ & $\begin{array}{c}\text { Group I } \\
\text { vs. } \\
\text { group III }\end{array}$ & $\begin{array}{c}\text { Group II } \\
\text { vs. } \\
\text { group III }\end{array}$ \\
\hline Age [years] & $52.4 \pm 8.5$ & $48.3 \pm 10.4$ & $49.8 \pm 10.4$ & $<0.05$ & $<0.05$ & NS \\
\hline LVEF [\%] & $22.0 \pm 8.5$ & $20.7 \pm 7.3$ & $19.4 \pm 6.1$ & $<0.05$ & $<0.05$ & NS \\
\hline LVEDD [mm] & $72.3 \pm 10.2$ & $72.2 \pm 11.8$ & $72.6 \pm 8.8$ & NS & NS & NS \\
\hline LVESD [mm] & $60.2 \pm 13.3$ & $61.1 \pm 12.0$ & $61.5 \pm 12.7$ & NS & NS & NS \\
\hline $\mathrm{HR}[/ \mathrm{min}]$ & $76.8 \pm 15.4$ & $77.7 \pm 14.7$ & $78.7 \pm 14.1$ & NS & NS & NS \\
\hline $\mathrm{SBP}[\mathrm{mm} \mathrm{Hg}]$ & $103.8 \pm 15.7$ & $98.5 \pm 11.6$ & $101.0 \pm 12.8$ & $<0.05$ & NS & NS \\
\hline $\mathrm{DBP}[\mathrm{mm} \mathrm{Hg}]$ & $67.1 \pm 11.6$ & $64.8 \pm 9.0$ & $67.1 \pm 9.7$ & $<0.05$ & NS & $<0.05$ \\
\hline $\mathrm{Na}[\mathrm{mEq} / \mathrm{L}]$ & $136.6 \pm 4.2$ & $136.3 \pm 4.2$ & $136.0 \pm 4.8$ & NS & NS & NS \\
\hline $\mathrm{VO}_{2} \max [\mathrm{mL} / \mathrm{min} / \mathrm{kg}]$ & $12.6 \pm 3.7$ & $12.3 \pm 3.5$ & $11.8 \pm 3.6$ & NS & NS & NS \\
\hline HFSS & $7.8 \pm 0.9$ & $7.6 \pm 0.9$ & $7.5 \pm 0.9$ & $<0.05$ & $<0.05$ & NS \\
\hline $\mathrm{mPAP}[\mathrm{mm} \mathrm{Hg}]$ & $19.9 \pm 3.1$ & $34.0 \pm 6.6$ & $38.4 \pm 7.8$ & $<0.05$ & $<0.05$ & $<0.05$ \\
\hline PCWP [mm Hg] & $14.1 \pm 3.0$ & $26.6 \pm 6.5$ & $27.0 \pm 7.4$ & $<0.05$ & $<0.05$ & NS \\
\hline TPG [mm Hg] & $7.7 \pm 3.9$ & $8.1 \pm 3.5$ & $15.6 \pm 5.8$ & NS & NS & NS \\
\hline Cardiac index $\left[\mathrm{L} / \mathrm{min} / \mathrm{m}^{2}\right]$ & $2.2 \pm 1.2$ & $1.9 \pm 0.5$ & $1.6 \pm 0.5$ & NS & $<0.05$ & $<0.05$ \\
\hline PVR [WU] & $2.2 \pm 1.3$ & $2.1 \pm 0.7$ & $4.8 \pm 1.7$ & NS & $<0.05$ & $<0.05$ \\
\hline hs-CRP [mg/L] & $3.0(0.1-114.3)$ & $3.0(0.1-68.7)$ & $3.8(0.1-62.1)$ & NS & NS & NS \\
\hline NT-proBNP [pg/mL] & 1695 (123-29873) & $3113(77-45515)$ & $4240(88-38829)$ & $<0.05$ & $<0.05$ & NS \\
\hline
\end{tabular}

$\mathrm{PH}$ - pulmonary hypertension; other abbreviations as in Table 1

Structural changes in venous and arterial pulmonary circulation are secondary to elevated LV filling pressure, and decreased left atrial and pulmonary vein compliance. Such structural consequences are well known in mitral stenosis, but there are few papers focused on such changes in patients with advanced HF [14-17]. In both models the rise of pressure in pulmonary circulation leads to certain changes in the function and morphology of arteries and veins. There are selected publications taking into account the problems above. Some of them underline that patients with higher levels of pre HTx PAP have a residual PH even three years after transplantation, suggesting the presence of structural changes [14, 18]. There are also some suggestions that PH referred to as "fixed" because of little or no reversibility with pharmacological tests or treatments before HTx, represents a major risk factor for prognosis after HTx, because of structural vascular remodelling. Delgado described advanced changes in media thickness assessed after HTx in a group of patients with reactive $\mathrm{PH}$ as compared to structural changes among those with passive $\mathrm{PH}$ [19]. A similar pathology was described by Hasleton and Brooks [20]. Khush et al. [9], using comparable methods to describe patients with mixed (reactive) $\mathrm{PH}$, proved that this kind of $\mathrm{PH}$ was common in patients with HF but did not predict poor short-term clinical outcomes. They underlined that patients with advanced HF in NYHA class IV generally had poor prognosis, and $\mathrm{PH}$ or no $\mathrm{PH}$ was no longer a significant prognostic factor.

Remodelling of pulmonary vasculature could be assessed taking into account the difference between diastolic PAP and PCWP when PVR is known. According to Engelberg and Dubios [21], experimental findings show that the difference (diastolic pulmonary gradient) could be used to assess diastolic PAP compliance. Tedford et al. [22], using the UNOS database, selected patients with $\mathrm{PH}(\mathrm{mPAP} \geq 25 \mathrm{~mm} \mathrm{Hg})$. Diastolic pulmonary gradient has no effect on patient's survival until five years after HTx, irrespective of TPG and PVR. The authors underlined that TPG is independent of cardiac output and so better reflects vascular compliance than PVR alone [22]. Results of Tedford extended our findings concerning prognosis of patients with $\mathrm{PH}$ after HTx. There is also important information (not published) that, irrespective of vasodilator testing for reversibility of $\mathrm{PH}$, there is no difference in six-month survival (21\% vs. $22 \%$ ) between those with or without reactive $\mathrm{PH}$ [9]. Among patients with advanced $\mathrm{HF}$ and $\mathrm{PH}$, right ventricular function significantly influences their prognosis, but right ventricular dysfunction with normal PAP poses no additional risk [23, 24]. Aronson et al. [5], whose methodology describing $\mathrm{PH}$ was used in our study, found 
significant differences in prognosis between patients with reactive $\mathrm{PH}$ as compared to patients with no $\mathrm{PH}$ or passive $\mathrm{PH}$. It should be underlined that the population of patients with HF was different. They were patients with acute HF included in a randomised trial, so the patients and the way of assessing the results were different. The authors estimated survival according to post-treatment $\mathrm{PH}$ categories. In a retrospective analysis, when $\mathrm{PH}$ was assessed before treatment, the survival of compared groups was nearly identical [5] and comparable to ours. Our registry covered a homogenous cohort of patients with chronic HF listed for elective HTx. There were patients treated according to the guidelines by appropriate in- and outpatient departments.

The most intriguing finding of our study was that the survival of patients with reactive $\mathrm{PH}$, who met the criteria of reversibility, was comparable with patients with no $\mathrm{PH}$ or passive $\mathrm{PH}$.

\section{Limitations of the study}

The results of the study were based on the data taken from the national registry of patients listed for HTx. The measurements of pulmonary haemodynamicity were not standardised; moreover, there were no available data concerning $\mathrm{PH}$ reversibility. Because of a necessary simplification of the registry, some data were not recorded, namely data concerning right ventricular function and details concerning treatment.

We decided to follow the Aronson classification of $\mathrm{PH}$ because of specificity of patients qualified to HTx [5]. It is a group of patients in whom PCWP is high, and consequently TPG is relatively low; moreover, TPG has no influence on patient survival irrespective of the analysed group.

Finally, the groups of patients with no $\mathrm{PH}$, passive $\mathrm{PH}$, or reactive $\mathrm{PH}$ were relatively small and the follow-up was short, not including the patient's survival after HTx. Thus the data concerning factors influencing survival and prognosis should be interpreted with caution.

\section{CONCLUSIONS}

Pulmonary hypertension is the result of longstanding left ventricular HF. Our results indicate that reactive $\mathrm{PH}$ is common in ambulatory patients with advanced HF listed for elective $\mathrm{HTx}$. Reactive $\mathrm{PH}$ has no further influence on prognosis at this stage of disease, despite the fact that patients with reactive $\mathrm{PH}$ had the worst pulmonary haemodynamic scores.

\section{POLKARD HF Investigators}

Institute of Cardiology, Warsaw: J. Korewicki, A. Browarek, T. Zieliński, M. Sobieszczańska-Małek, M. Karczmarz, J. Różański, J. Wołczyk, P. Kołsut, W. Piotrowski

Silesian Centre for Heart Disease, Zabrze: M. Zembala, L. Poloński, M. Zakliczyński, P. Rozentryt, J. Nowak, T. Kukulski, M. Świerad, A. Barańska-Kosakowska
Department of Heart, Vascular, and Transplantology Surgery, Krakow: J. Sadowski, P. Przybyłowski, D. Sobczyk, K. Wierzbicki

Department of Cardiac Surgery Central Clinical Hospital of the Ministry of Interior Hospital, Warsaw: M. Garlicki, Ł. Chojecki, K. Roguski

This study was supported by the National Ministry of Health grant: POLKARD 1304/IK-AG-K283/03 Clinical trials.gov. no. NCT00690157.

\section{Conflict of interest: none declared}

\section{References}

1. Moraes D, Colucci W, Givertz M. Secondary pulmonary hypertension in chronic heart failure. Circulation, 2000; 102: 1718-1723. doi: 10.1161/01.CIR.102.14.1718.

2. Guazzi M, Arena R. Pulmonary hypertension with left-sided heart disease. Nat Rev Cardiol, 2010; 7: 648-659.

3. Hoeper MM, Barberà JA, Channick RN et al. Diagnosis, assesment and treatment of non-pulmonary arterial hypertension pulmonary hypertension. J Am Coll Cardiol, 2009; 54: S85-S96. doi: 10.106/j.jacc.2009.04.008

4. Aaronson K, Schwartz J, Chen T et al. Development and prospective validation of clinical index to predict survival in ambulatory patients referred for cardiac transplant evaluation. Circulation, 1997; 95: 2660-2667. doi: 10.1161/01.CIR.95.12.2660.

5. Aronson D, Eitan A, Dragu R et al. Relationship between reactive pulmonary hypertension and mortality in patients with acute decompensated heart failure. Circ Heart Fail, 2011; 4: 644-650. doi: 10.1161/CIRCHEARTFAILURE.110.960864.

6. Chatterjee N, Lewis G. What is the prognostic significance of pulmonary hypertension in heart failure? Circ Heart Fail, 2011; 4: 541-545. doi: 10.1161/CIRCHEARTFAILURE.111.963785.

7. Simonnean G, Robins I, Beghetti M et al. Updated clinical classification of pulmonary hypertension. J Am Coll Cardiol, 2009; 54: S43-S54. doi:10.1016 /j.jacc. 2009. 04.012.

8. Grigioni F, Potena L, Galie N et al. Prognostic implications of serial assessment of pulmonary hypertension in severe chronic heart failure. J Heart Lung Transplant, 2006; 25: 1241-1246. doi: 10.1016/j.healun.2006.06.015.

9. Khush K, Tasissa G, Butler J et al. Effect of pulmonary hypertension on clinical outcomes in advanced heart failure: analysis of the evaluation study of congestive heart failure and pulmonary artery catheterisation effectiveness (ESCAPE) database. Am Heart J, 2009; 157: 1026-1034. doi: 10.1016/j.ahj.2009.02.022.

10. Costard-Jackle A, Flower M. Influence of preoperative pulmonary artery pressure on mortality after heart transplantation: testing of potential reversibility of pulmonary hypertension with nitroprusside is useful in defining a high risk group. J Am Coll Cardiol, 1992; 19: 48-54. doi: 10.1016/0735-1097(92)90050.

11. Mancini D, Lietz K. Selection of cardiac transplantation candidates in 2010. Circulation, 2010; 122: 173-183. doi: 10.1161/CIRCULATIONAHA.109.858076.

12. Abramson SV, Burke JF, Kelly JJ et al. Pulmonary hypertension predicts mortality and morbidity in patients with dilated cardiomiopathy. Ann Intern Med, 1992; 116: 888-895. doi: 10.7326/0003-4819-116-11-888.

13. Oudiz R. Pulmonary hypertension associated with left-sided heart disease. Clin Chest Med, 2007; 28: 233-241.

14. Wagenvoort C, Mooi W. Congestive vasculopathy. In biopsy pathology of the pulmonary vasculature. Chapman \& Hall Medical, London 1989; 171-198. 
15. Pogorzelska H, Korewicki J. The role of endothelin-1 and pulmonary artery compliance in patients with secondary pulmonary hypertension. Curr Pneumol, 1999; 1: 19-23.

16. Pogorzelska H, Korewicki J, Zieliński T et al. Prognostic significance of changes in the compliance of the pulmonary venous system after isosorbiddinitrate in patients with mitral stenosis. Int J Cardiol, 1995; 42: 57-62.

17. Delgado J, Conde J, Sanchez V. Pulmonary vascular remodelling in pulmonary hypertension due chronic heart failure. Eur J Heart Fail, 2005; 7: 1011-1016. doi: 10.1016/j.ejheart.2004.10.021.

18. Wagenvoort CA, Wagenvoort N. Pulmonary venous hypertension. In: Wagenvoort CA, Wagenvoort N eds. Pathology of pulmonary hypertension. John Wiley and Sons, New York 1977; 177-216.

19. Delgado JF, Gomez-Sanchez MA, Saenz de la Calzada C et al. Impact of mild pulmonary hypertension on mortality and pulmonary pressure profile after heart transplantation. J Heart Lung Transplant, 2001; 20: 942-948. doi: 10.1016/S10532498(01)00286-8.
20. Haselton P, Brooks N. Severe pulmonary vascular change in patients dying with right ventricular failure after heart transplantation. Thorax, 1995; 50: 210-212. doi: 10.1136/thx.50.2.210.

21. Engelberg J, Dubios A. Mechanics of pulmonary circulation in isolated rabbit lung. Am J Physiol, 1959; 196: 401-414.

22. Tedford RJ, Beaty CA, Mathai SC et al. Prognostic value of the pre-transplant capillary wedge pressure gradient in cardiac transplant recipients with pulmonary hypertension. J Heart Lung Transplant, 2014; 33: 289-297. doi: 10.1016/j.healun.2013.11.008.

23. Ghio S, Gavazzi A, Campana $\mathrm{C}$ et al. Independent and additive prognostic value of right ventricular systolic function and pulmonary arterial pressure in patients with chronic heart failure. J Am Coll Cardiol, 2001; 37: 183-188. doi: 10.1016/S07351097(00)01102-5.

24. Ghio S, Temporelli PL, Klersy C et al. Prognostic relevance of non-invasive evaluation of right ventricular function and pulmonary artery pressure in patients with chronic heart failure. Eur J Heart Fail, 2013; 15: 408-414. doi: 10.1093/eurjhf/hfs208.

Cite this article as: Sobieszczańska-Małek M, Zieliński T, Piotrowski W, Korewicki J. Prognostic significance of reactive pulmonary hypertension in patients with chronic heart failure listed for elective heart transplantation. Kardiol Pol, 2016; 74: 733-740. doi: 10.5603/KP.a2015.0252.

\section{W imieniu Komitetu Naukowego \\ XXI Sympozjum Sekcji Kardiologii Eksperymentalnej PTK oraz Komitetu Nauk Fizjologicznych i Farmakologicznych PAN zapraszamy do uczestnictwa w konferencji naukowej, która odbędzie się w dniach \\ 13-15 października 2016 roku w Ryni.}

\section{Abstrakty prosimy przesyłać na adres: sympozjumptk@wum.edu.pl do 31 sierpnia 2016 roku.}

W pierwszym dniu konferencji zapraszamy na wykład inauguracyjny pt. „Kardiologia eksperymentalna — najnowsze trendy i perspektywy”, który wygłosi prof. dr hab. n. med. Maciej Kurpisz.

Dzień drugi i trzeci są przeznaczone w całości na kilka sesji tematycznych, podczas których, zgodnie z wieloletnią tradycją, pod okiem ekspertów

będzie możliwość wspólnego przedyskutowania wyników Państwa ostatnich osiągnięć naukowych.

W tym roku po raz pierwszy organizujemy, zgodnie z Państwa życzeniem, sesję plakatową i sesję w języku angielskim. Mamy nadzieję, że nasza konferencja, przygotowana i prowadzona przez miłośników kardiologii eksperymentalnej, zyska Państwa uznanie.

Serdecznie zapraszamy i do zobaczenia w Ryni! Strona internetowa: sympozjumptk.wum.edu.pl 


\title{
Znaczenie prognostyczne reaktywnego nadciśnienia płucnego u pacjentów z przewlekłą niewydolnością serca kwalifikowanych do transplantacji serca
}

\author{
Małgorzata Sobieszczańska-Małek ${ }^{1}$, Tomasz Zieliński ${ }^{1}$, Walerian Piotrowski ${ }^{2}$, Jerzy Korewicki ${ }^{1}$ \\ ${ }^{1}$ Klinika Niewydolności Serca i Transplantologii, Instytut Kardiologii, Warszawa \\ 2Zakład Epidemiologii, Prewencji Chorób Układu Krążenia i Promocji Zdrowia, Instytut Kardiologii, Warszawa
}

\section{Streszczenie}

Wstęp: Nadciśnienie płucne (PH) rozpoznaje się u ok. 60\% pacjentów rozpatrywanych jako kandydatów do transplantacji serca (HTx), co wpływa na przebieg kliniczny.

Cel: Celem pracy było określenie wartości prognostycznej reaktywnego PH pacjentów kwalifikowanych w trybie planowym do HTx.

Metody: Analizowano dane 522 pacjentów biorących udział w rejestrze POLKARD kwalifikowanych do HTx, u których wykonano cewnikowanie prawego serca. Punktem końcowym badania były wszystkie przypadki zgonu przed transplantacją serca. Przeprowadzenie HTx w trybie planowym lub pilnym uznano za koniec obserwacji (średni czas obserwacji 1,47 $\pm 1,26$ roku). Pacjenci zostali podzieleni na trzy podgrupy: bez $\mathrm{PH}$, z $\mathrm{PH}, \mathrm{z}$ reaktywnym $\mathrm{PH}$, a jako punkt odniensienia brano pod uwagę wartości średniego ciśnienia w tętnicy płucnej (PAP) $25 \mathrm{~mm} \mathrm{Hg}$, ciśnienia zaklinowania we włośniczkach płucnych (PCWP) 15 mm Hg i naczyniowego oporu płucnego (PVR) 3,0 j. Wooda. Przeprowadzano ocenę kliniczną oraz wykonywano badania hemodynamiczne, echokardiograficzne i biochemiczne krwi (m.in. NT-proBNP, hs-CRP). Wyliczano też wartość Heart Failure Survival Score (HFSS).

Wyniki: Śmiertelność była porównywalna między grupami, mimo że w badaniach hemodynamicznych pacjentów z reaktywnym PH wyniki były najwyższe (średnie PAP 38,4 \pm 7,8, PCWP $27 \pm 7,4$ mm Hg, PVR 4,8 \pm 1,7 j. Wooda). W grupie pacjentów z reaktywnym PH w wieloczynnikowej analizie Coxa tylko stężenie sodu wpływało na przeżycie. Na podstawie analizy metodą Kaplana-Meiera stwierdzono, że pacjenci z reaktywnym PH, ze średnim PAP $\geq 41,4 \mathrm{~mm} \mathrm{Hg}$, charakteryzowali się najgorszym rokowaniem, a szacunkowe przeżycie jednoroczne i dwuletnie wynosiło odpowiednio 83\% i 65\%.

Wnioski: Reaktywne PH jest częstym zjawiskiem u osob z przewlekłą niewydolnością serca kwalifikowanych do HTx. Nie ma to dalszego wpływu na krótkotrwałe rokowanie w porównaniu z pacjentami bez $\mathrm{PH}$ lub z PH. Stężenie sodu i średnie PAP $\geq 41,4$ mm Hg wpływa na rokowanie pacjentów z reaktywnym nadciśnieniem płucnym.

Słowa kluczowe: transplantacja serca, nadciśnienie płucne

Kardiol Pol 2016; 74, 8: 733-740 